\title{
Mercury pollution in Ria de Aveiro (Portugal): a review of the system assessment
}

\author{
M. E. Pereira • A. I. Lillebø • P. Pato • M. Válega • J. P. Coelho • C. B. Lopes • \\ S. Rodrigues - A. Cachada $\cdot$ M. Otero $\cdot$ M. A. Pardal - A. C. Duarte
}

Received: 16 January 2008 / Accepted: 22 May 2008

(C) Springer Science + Business Media B.V. 2008

\begin{abstract}
The Ria de Aveiro (Portugal) is a coastal lagoon adjacent to the Atlantic Ocean and it has an inner bay (Laranjo bay) that received a highly contaminated effluent discharged by a mercury cell chlor-alkali plant from the 1950s until 1994. The aim of this study is to review in a holistic way several research studies that have been carried out in the Ria de Aveiro, in order to evaluate the remobilization of the mercury accumulated within the system and the recovery of the lagoon. The spatial distribution of the total mercury in the surrounding terrestrial environment has also been considered. Results indicate that the main mercury contamination problems in the Ria de Aveiro are confined to the Laranjo bay. Mercury export to the coastal waters and its impact
\end{abstract}

M. E. Pereira $(\varangle) \cdot$ A. I. Lilleb $\varnothing \cdot$ P. Pato .

M. Válega · J. P. Coelho · C. B. Lopes · S. Rodrigues ·

A. Cachada - M. Otero - A. C. Duarte

CESAM-Centre for Environment and Marine

Studies, Department of Chemistry,

University of Aveiro, Campus de Santiago,

3810-193, Aveiro, Portugal

e-mail: eduper@ua.pt

A. I. Lilleb $\varnothing$

e-mail: lillebo@ua.pt

M. A. Pardal

IMAR - Institute of Marine Research,

Department of Zoology, University of Coimbra,

3004-517, Coimbra, Portugal on the nearshore compartments (water column, sediment and biota) are low. No direct effects of the mercury from nearby industrial activities were detected in Aveiro's urban soils, although historical mercury contamination is still affecting soil quality in the immediate vicinity of the chlor-alkali plant, located in Estarreja. Moreover, macrophyte harvesting for human direct or indirect use and the consumption of mussels, crabs and the sea bass from the Laranjo bay may constitute a health risk. Further studies focusing on developing skills for the restoration of the ecosystem are presently underway.

Keywords Anthropogenic mercury contamination - Coastal management • Environmental assessment • Key environmental processes

\section{Introduction}

Mercury $(\mathrm{Hg})$ is one of the most hazardous contaminants that may be present in aquatic environments, widely considered to be among the highest priority environmental pollutants in the scope of the European Water Framework Directive (WFD) and on the global scale. Although, the existing restrictions on anthropogenic sources of mercury, historically contaminated sediments may still constitute a source of mercury to the aquatic 
environment, becoming available to aquatic organisms (e.g. Alonso et al. 2000; De Marco et al. 2006). In contaminated environments mercury (in the organic and inorganic forms) may be transferred from the abiotic to the biotic compartment (e.g. Baeyers et al. 2003; De Marco et al. 2006; Donkor et al. 2006). Once in biota other processes may occur, namely the increase of mercury concentrations in fish (Abreu et al. 2000; Baeyers et al. 2003; De Marco et al. 2006), or in shell-fish (Coelho et al. 2006) with age (bioaccumulation); higher mercury concentration in seston (Baeyers et al. 2003) or in macroalgae (Cairrão et al. 2007) than in the water column (bioconcentration); or the increase of mercury concentrations through the trophic chain (biomagnification) (Baeyers et al. 2003; De Marco et al. 2006).

It is recognised that anthropogenic sources of mercury are responsible for the highest environmental impacts (EPA 1997), having deleterious effects on biota, including both Human health and ecosystem functions. It has been recognised that Humans may be affected, namely through fish and shell-fish consumption, although, the exposure to areas with high mercury levels (in organic and inorganic forms) in multiple environmental compartments may also represent a risk to human health (Baeyers et al. 2003; Donkor et al. 2006).

In face of historical contamination by mercury, several coastal systems in the world have been assessed in an integrated way (Table 1). Most of the anthropogenic mercury enters these coastal systems in its inorganic form through diffuse sources or via point discharges (Baeyers et al. 2003). Once in the aquatic system, mercury can also be transported far from the source, impacting the downstream environment (e.g. Donkor et al. 2006). Some of these cases can be illustrated by the following worldwide examples: in three coastal systems located at the littoral of Buenos Aires Province, Argentina, (De Marco et al. 2006) and in the in Mugu Lagoon, southern California, USA, (Rothenberg et al. 2008), anthropogenic sources are related to urban and industrial activities and land drainage; in Pra river Basin, (southwestern Ghana) it is related to artisanal gold mining with metallic mercury (Donkor et al. 2006); while in Venice lagoon, Italy (Bloom et al. 2004), Cartagena bay, Colombia (Alonso et al. 2000), and Ulhas estuary, India, (Ram et al. 2003), mercury contamination is mostly related to extinct chlor-alkali plants. All the refereed systems were assessed concerning the sediment compartment and for the most cases analysis in fish tissues was included (Table 1). As an example of some of the results and main conclusions: in Cartagena Bay, $20 \%$ of the specimens of one of the fish species collected had more than $100 \mu \mathrm{g} \mathrm{Hg} \mathrm{kg} \mathrm{H}^{-1}$, wet weight, although $\mathrm{Hg}$ concentrations were always below the international human consumption advisory limit (500 $\mu \mathrm{g} \mathrm{Hg} \mathrm{kg}^{-1}$, wet weight) (Alonso et al. 2000). However, authors point out that due to the high levels of $\mathrm{Hg}$ in the sediments of Cartagena Bay, the imminent risk of $\mathrm{Hg}$ contamination through the consumption of fish could represent a risk to Human health. For Samborombón Bay (Argentina) De Marco et al. (2006) suggest that, to date, biota does not have high mercury levels due to the existence of a mechanism of mercury immobilization within the estuarine sediments, since concentration of mercury in the abiotic matrices is one order of magnitude higher than in biological ones (respectively, 10,000-15,000 $\mathrm{ng} \mathrm{g}^{-1}$, dry weight, and less than $1,000 \mathrm{ng} \mathrm{g}^{-1}$, wet weight). In Pra river Basin, Donkor et al. (2006) found a seasonal variation of levels of $\mathrm{Hg}$ in Human hair linked to the consumption of fish, although always far below the guideline recommended by the World Health Organization.

The Ria de Aveiro coastal lagoon (Portugal) is adjacent to the Atlantic Ocean and it has an inner bay (Laranjo bay, Fig. 1) that received a highly contaminated effluent discharged from a mercury cell chlor-alkali plant located in Estarreja industrial complex, from the 1950s until 1994. The discharges resulted in an accumulation of about $33 \mathrm{t}$ of mercury in the lagoon, much of which (about $27 \mathrm{t}$ ) is known to be sediment-associated (entirely in the particulate fraction) in the Laranjo bay (Pereira et al. 1998a). In the last decade, the mercury discharge diminished considerably, being nowadays within the regulatory levels $\left(50 \mu \mathrm{g} \mathrm{l^{-1 }}\right.$, the limit value for discharges from chlor-alkali electrolysis industry, in accordance with Directive 82/176/EEC 1982). However, mercury concentrations in the surface sediments of some areas of the Ria are still higher than pre-industrial levels, 


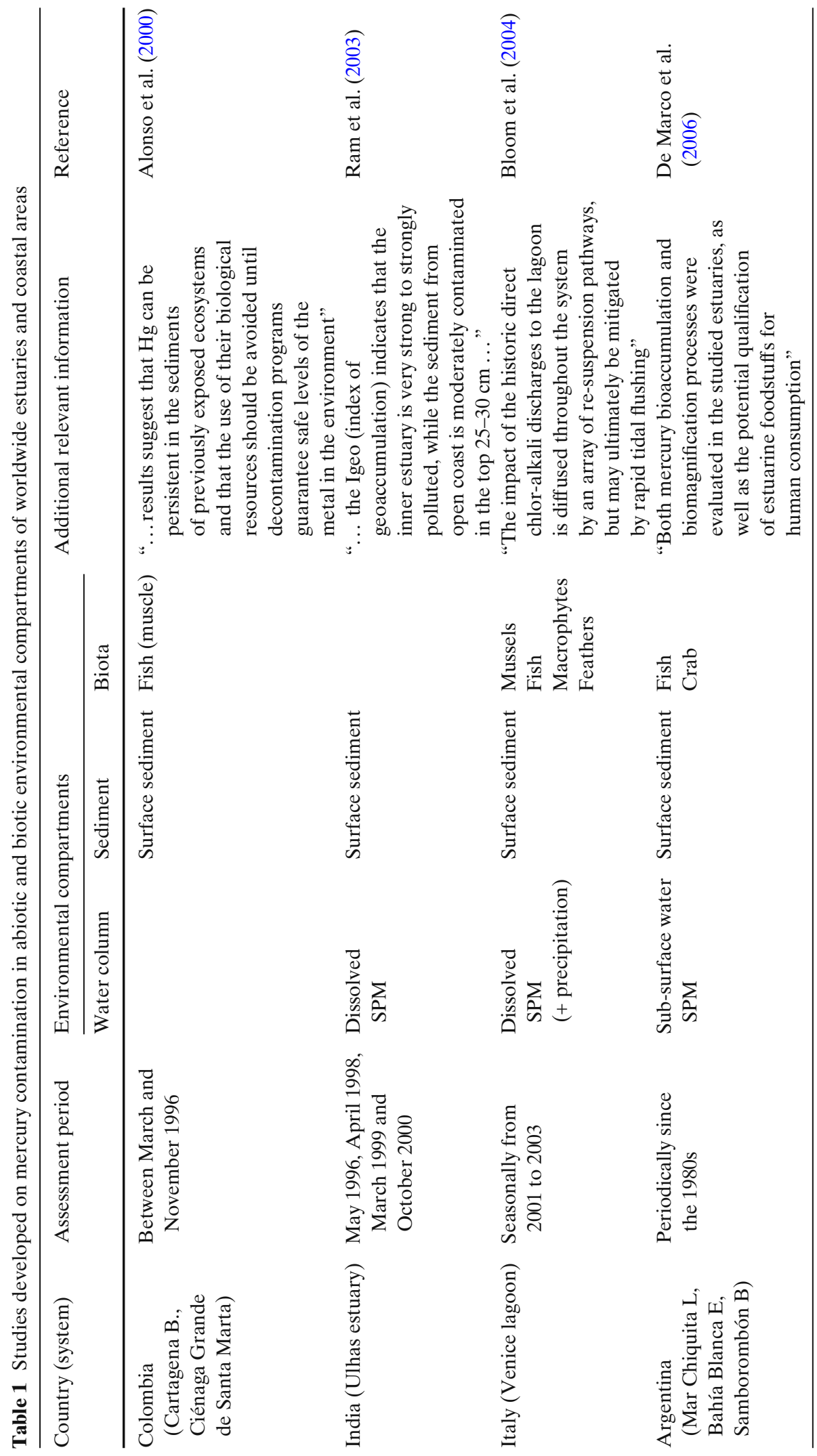


namely in the Laranjo bay (a shallow area with $2 \mathrm{~km}^{2}$ ) with values in the range of $2.5-51.7 \mu \mathrm{g}$ $\mathrm{Hg} \mathrm{g}^{-1}$ (Coelho et al. 2005). During the last two decades several studies have been carried out separately in abiotic (e.g. Pereira et al. 1998a, b; Ramalhosa et al. 2006) and biotic (e.g. Abreu et al. 2000; Monterroso et al. 2003; Coelho et al. 2005, 2006; Pereira et al. 2006; Válega et al. 2008a, b) compartments of the system. At the system level, the fluxes of mercury to the Atlantic Ocean (Pato et al. 2008a) and the impact of mercury pollution on the nearshore waters (Pato et al. 2008b) were assessed, as well as the spatial distribution of total mercury in terrestrial environment surrounding the lagoon (Rodrigues et al. 2006b; Cachada et al. 2008). Concerns now exist about the future environmental health of the Ria and attempts have been made to understand the processes affecting the historical load of mercury as well as its impacts on ecosystems' functioning.

This review is based on the integrated assessment of mercury pollution problems in Ria de Aveiro and considers all studies developed in the different key environmental compartments of the system during the last two decades highlighting current concerns and data gaps.

\section{Materials and methods}

Study site

The Ria de Aveiro supports a population of 250,000 inhabitants in the watershed area, and its main municipality (Aveiro town) is located $15 \mathrm{~km}$ south from an industrial complex located in Estarreja, that includes a chlor-alkali plant that have discharged mercury from the 1950s until the mid 1990s.

Ria de Aveiro is a shallow well-mixed coastal lagoon on the northwestern coast of Portugal $\left(40^{\circ} 38^{\prime} \mathrm{N}, \mathrm{O}^{\circ} 45^{\prime} \mathrm{W}\right)$ connected to the sea by a single channel $(1.3 \mathrm{~km}$ long, $350 \mathrm{~m}$ wide and $20 \mathrm{~m}$ deep). The system is $45 \mathrm{~km}$ long (NNESSW direction) with a maximum width of $10 \mathrm{~km}$, and covers an area of approximately $83 \mathrm{~km}^{2}$ of wetland in high tide (spring tide) and $66 \mathrm{~km}^{2}$ in low tide (Dias and Fernandes 2006; Abrantes et al. 2006). The topography of Ria de Aveiro consists 


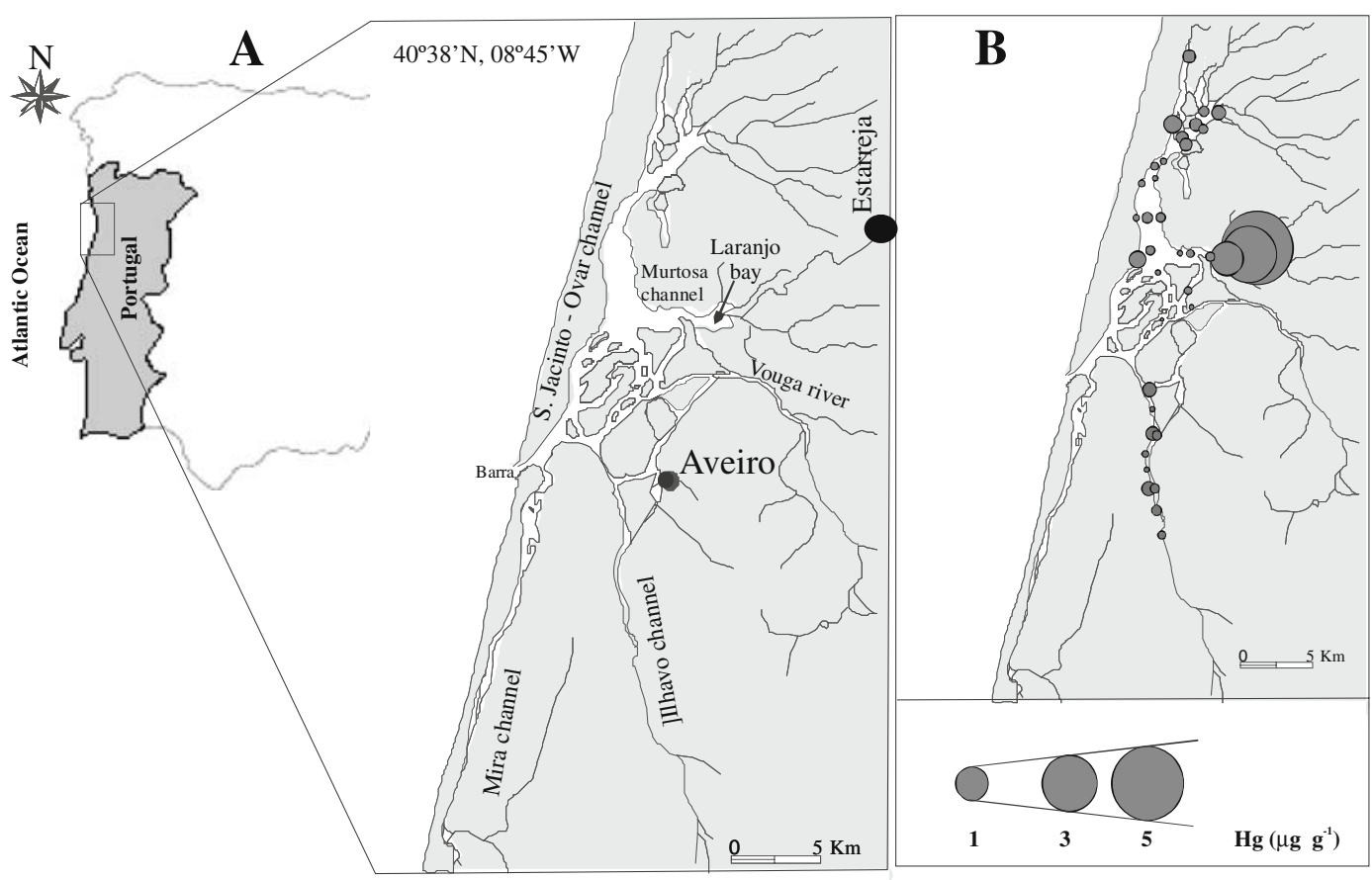

Fig. 1 A The location of Ria de Aveiro. B Total mercury concentrations ( $\mu \mathrm{g} \mathrm{g}^{-1}$, dry weight) in surface sediments of Ria de Aveiro (redrawn after Pereira et al. 2006)

of channels which radiate from the mouth with several branches, islands and mudflats (Fig. 1): the Mira and Ílhavo channels run to the south and are narrow and shallow; the S. Jacinto-Ovar channel lies to the north and is wide and deep in its southern part but changes northwards, forming secondary narrow and shallow channels and bays (the Murtosa channel and the Laranjo bay). The system mean depth is about $1 \mathrm{~m}$, except in the navigation channels where dredging operations maintain a depth of about $7 \mathrm{~m}$ (Dias et al. 2000). The estimated lagoon tidal prism is $136.7 \mathrm{Mm}^{3}$ for maximum spring tide and $34.9 \mathrm{Mm}^{3}$ for minimum neap tide (Dias et al. 2000). The total mean river discharge into the lagoon during a tidal cycle is small (about $1.8 \mathrm{Mm}^{3}$ ) when compared with the tidal prism and therefore semidiurnal tides are the major factor influencing the hydrodynamics of the lagoon (Dias et al. 2000).

\section{Sampling and analytical procedures}

Water, sediment/soil and biota sampling, sample treatment and analysis were always done using standard ultra-clean protocols following internationally standardized methods. Quality control of the analytical methods was also ensured by analysis of adequate certified reference materials (CRM). For more detailed information see the material and methods sections of the respective studies (references in Tables 2 and 3).

\section{Results and discussion}

The assessment of mercury pollution in abiotic environmental compartments of Ria de Aveiro (Table 2) has shown that the Laranjo bay area presents the highest mercury concentrations concerning the water column (total mercury in filtered water and in suspended particulate matter) and the sediment (surface sediment and sediment pore water), while the lowest values were recorded in Ria nearshore. A more detailed study at the Laranjo bay (Ramalhosa et al. 2006) showed that mercury present in the solid fraction of the sediments is mostly associated with organic 
Table 2 Mercury contamination in abiotic environmental compartments of Ria de Aveiro (excluding the Laranjo bay), of Laranjo bay (Laranjo) and of Ria nearshore
Atlantic waters (SPM-suspended particulate matter; dwtdry weight; mean values \pm std. dev.; * reactive mercury concentration represented 3.7 to $21 \%$ of total mercury)

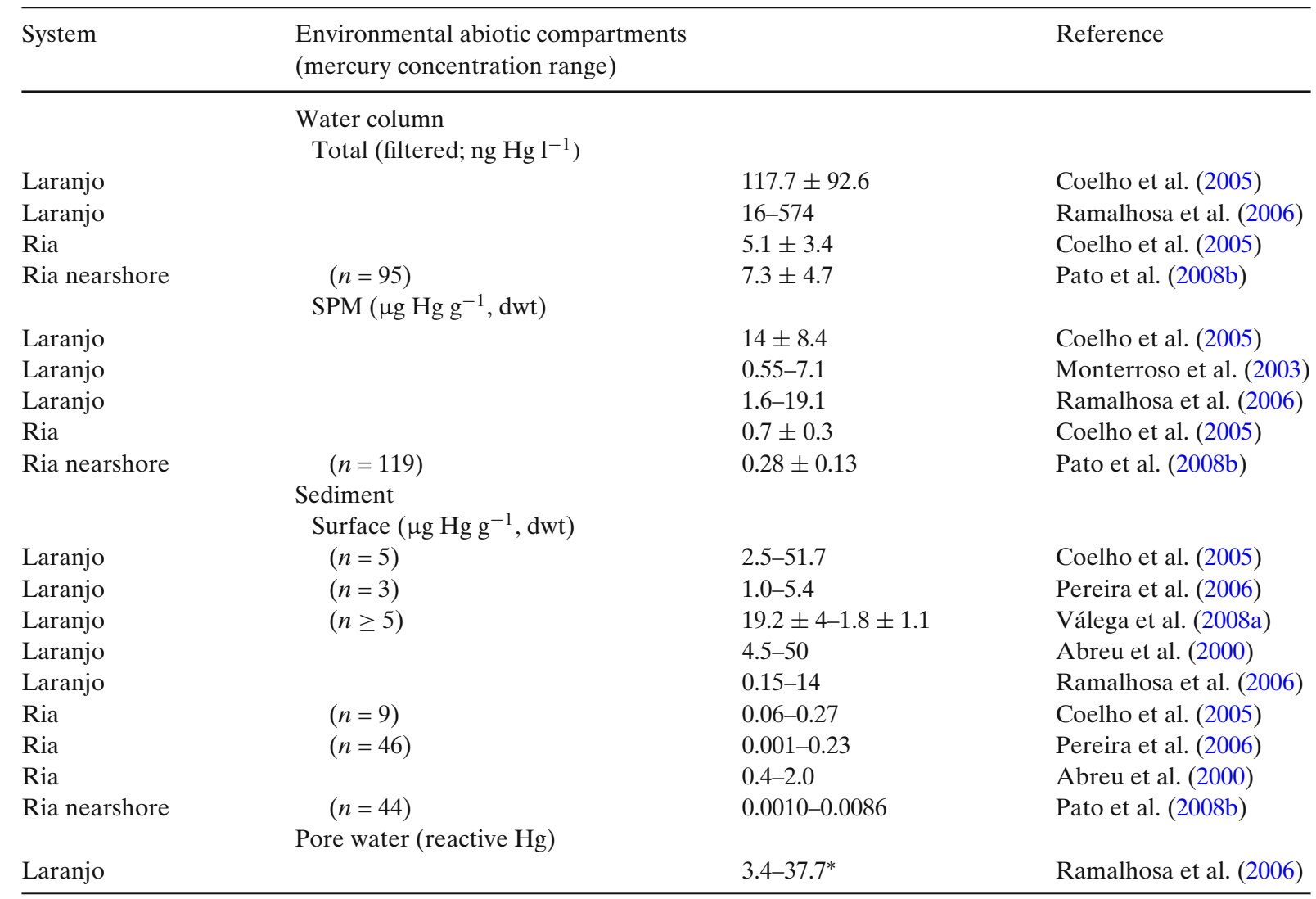

matter $(r=0.84)$ and with iron oxyhydroxides $(r=0.92)$. Yet, although the pore water concentrations largely exceed the overlaying water ones (Table 2), mercury diffusion calculations suggests that the mercury cycling between the water column and the surface sediments is not relevant in this system once the fluxes are of the order of 0.25-11.9 $\mathrm{ng} \mathrm{Hg} \mathrm{m}^{-2} \mathrm{~h}^{-1}$ (Ramalhosa et al. 2006). In fact, the same authors calculated that the dissolved reactive and non-reactive mercury present in pore waters contributed only $0.2 \%$ and $0.5 \%$ to the water column enrichment, respectively, showing that, as long as mercury is being incorporated in sediments, it stays in stable forms. Nevertheless, problems derived from mercury contamination are enhanced when mercury enters food chains (e.g. Lawson and Mason 1998; Baeyers et al. 2003) and primary producers like macroalgae may represent an important pathway for mercury incorporation in estuarine food webs (Coelho et al. 2005; Cairrão et al. 2007). Table 3, resumes the assessment of mercury pollution in biotic environmental compartments of Ria de Aveiro, specifically in primary producers. Results show that the highest concentrations of total mercury in macroalgae were found at the Laranjo bay (Table 3). In addition, Gracilaria sp. and Fucus sp., showed a good agreement with environmental mercury contamination within Ria (sediment and water), while mercury concentrations in Enterophorpha sp. seemed to be most dependent of water mercury levels (Coelho et al. 2005).

Results on the assessment of the Laranjo bay salt marsh species composition (Válega et al. 
Table 3 Mercury contamination in biotic environmental compartments of Ria de Aveiro (excluding the Laranjo bay), of Laranjo bay (Laranjo) and of Ria nearshore Atlantic waters

\begin{tabular}{|c|c|c|c|}
\hline System & Environmental biotic compartments & & Reference \\
\hline & Primary producers & & \\
\hline & Macroalga ( $\left.\mu \mathrm{g} \mathrm{Hg} \mathrm{g}^{-1}, \mathrm{dwt}\right)$ & & \\
\hline Laranjo & Enteromorpha $\mathrm{sp}$ & $0.37 \pm 0.45$ & Coelho et al. (2005) \\
\hline Laranjo & Gracilaria $\mathrm{sp}$ & $0.34 \pm 0.25$ & Coelho et al. (2005) \\
\hline Laranjo & Fucus sp & $0.47 \pm 0.1$ & Coelho et al. (2005) \\
\hline Ria & Enteromorpha sp & $0.09 \pm 0.08$ & Coelho et al. (2005) \\
\hline Ria & Gracilaria $\mathrm{sp}$ & $0.04 \pm 0.04$ & Coelho et al. (2005) \\
\hline \multirow[t]{2}{*}{ Ria } & Fucus sp & $0.05 \pm 0.04$ & Coelho et al. (2005) \\
\hline & Salt marsh plants (ng $\mathrm{Hg} \mathrm{g}^{-1}$, dwt) & & \\
\hline \multirow[t]{3}{*}{ Laranjo } & A. fruticosum & & \\
\hline & Shoots & 95.9 & Válega et al. (2008b) \\
\hline & Roots & $11,350 \pm 930$ & Válega et al. (2008b) \\
\hline \multirow[t]{6}{*}{ Laranjo } & H. portulacoides & & \\
\hline & Stem & 26.5 & Válega et al. (2008b) \\
\hline & Leaves & 54.1 & Válega et al. (2008b) \\
\hline & Roots & $14,770 \pm 244$ & Válega et al. (2008b) \\
\hline & Fauna & & \\
\hline & Benthic fauna ( $\mu \mathrm{g} \mathrm{Hg} \mathrm{g}^{-1}$, wwt) & & \\
\hline Laranjo & Scobicularia plana & $0.37 \pm 0.26$ & Coelho et al. (2006) \\
\hline Laranjo & Carcinus maenas & $0.33 \pm 0.17$ & Pereira et al. (2006) \\
\hline Ria & Scobicularia plana & $0.03 \pm 0.01$ & Coelho et al. (2006) \\
\hline Ria & Carcinus maenas & $0.09 \pm 0.01$ & Pereira et al. (2006) \\
\hline Ria nearshore & Donax vittatus & $0.0085 \pm 0.0006$ & Pato et al. (2008b) \\
\hline \multirow[t]{2}{*}{ Ria nearshore } & Spisula solida & $0.014 \pm 0.005$ & Pato et al. (2008b) \\
\hline & Fish (muscle) $\left(\mu \mathrm{g} \mathrm{Hg} \mathrm{g}^{-1}, \mathrm{wwt}\right)$ & & \\
\hline Laranjo & Dicentrarchus labrax & Range $0.03-1.7$ & Abreu et al. (2000) \\
\hline Ria & Dicentrarchus labrax & Occasionally $>0.5$ & Abreu et al. (2000) \\
\hline Ria nearshore & Echiichthys vipera & $0.085 \pm 0.026$ & Pato et al. (2008b) \\
\hline Ria nearshore & Trigla lucerna & $0.043 \pm 0.012$ & Pato et al. (2008b) \\
\hline Ria nearshore & Dicologlossa cuneata & $0.12 \pm 0.04$ & Pato et al. (2008b) \\
\hline
\end{tabular}

Mean values \pm SD

$d w t$ : dry weight

$w w t$ : wet weight

2008a) showed that plants like Halimione portulacoides, Arthrocnemum fruticosum, Triglochin maritime, Juncus maritimus, Phragmites australis and Scirpus maritimus may be differently tolerant to mercury contamination, being $P$. australis the most tolerant (Válega et al. 2008b). A more detailed study of $H$. portulacoides and $A$. fruticosum within the Laranjo bay showed that total mercury concentrations in the below ground biomass were much higher (Table 3) suggesting that only a small fraction is translocated to the above ground portions of the plants (Válega et al. 2008a). Nevertheless, this area should not be used for agriculture or grazing for livestock, since its contamination may constitute an environmental and human health concern.

Like primary producers, especially rooted macrophytes, benthic fauna are also in close contact with the contaminated sediment. Table 3, resumes the assessment of mercury pollution in biotic environmental compartments of Ria de Aveiro and nearshore, specifically in fauna. Results show that fish (Abreu et al. 2000) and macrofauna (Coelho et al. 2006; Pereira et al. 2006) showed high accumulation of mercury in the Laranjo bay (Table 3). 
Ria functions as a natural laboratory due to its Human induced mercury gradient (Lucas et al. 1986; Pereira et al. 1998b), and Scrobicularia plana, a long-lived deposit feeding bivalve, was found to respond to this gradient, with increasing accumulation parallel to environmental mercury levels (Coelho et al. 2006). Carcinus maenas, the European shore crab is one of the most important and exploited natural resources in temperate estuarine systems. Results showed that in Laranjo bay these crabs constitute potential pathways of mercury transference to predatory species, including Humans (Pereira et al. 2006). At the system nearshore, macrofauna specimens, namely the banded wedge shell (Donax vittatus) and the clam (Spisula solida) (Pato et al. 2008b), presented mercury levels lower than regulatory limits (Table 3).

All the studied biota species (macrophytes, macrofauna and fish) showed higher levels of mercury contamination within the Laranjo bay than in the Ria de Aveiro and nearshore. Meaning, as also concluded by other authors, that the anthropogenic loading of mercury into the environment through industrial activities such as the production of chlor-alkali may represent a long-term source of this metal even years after the contamination input has been halted (Alonso et al. 2000; Bloom et al. 2004).

Concerning the migratory specimen Dicentrarchus labrax, authors occasionally found concentrations above regulatory limits $\left(0.5 \mu \mathrm{g} \mathrm{Hg} \mathrm{g}^{-1}\right.$ wet weight; EPA 2001) in other areas of the lagoon other than the Laranjo (Abreu et al. 2000). Within the Laranjo bay, this species showed an increase of mercury with the size, and juveniles showed higher concentrations than those captured in other parts of the lagoon, indicating a relatively rapid accumulation rate (Abreu et al. 2000). On the other hand, mercury concentration in specimens captured nearshore, namely lesser weever (Echiichthys vipera), tub gurnard (Trigla lucerna) and wedge sole (Dicologlossa cuneata) (Pato et al. 2008b) were always lower than regulatory limits for Human consumption (Table 3).

An integrative schematic representation of mercury contamination in abiotic and biotic environmental compartments of Ria de Aveiro

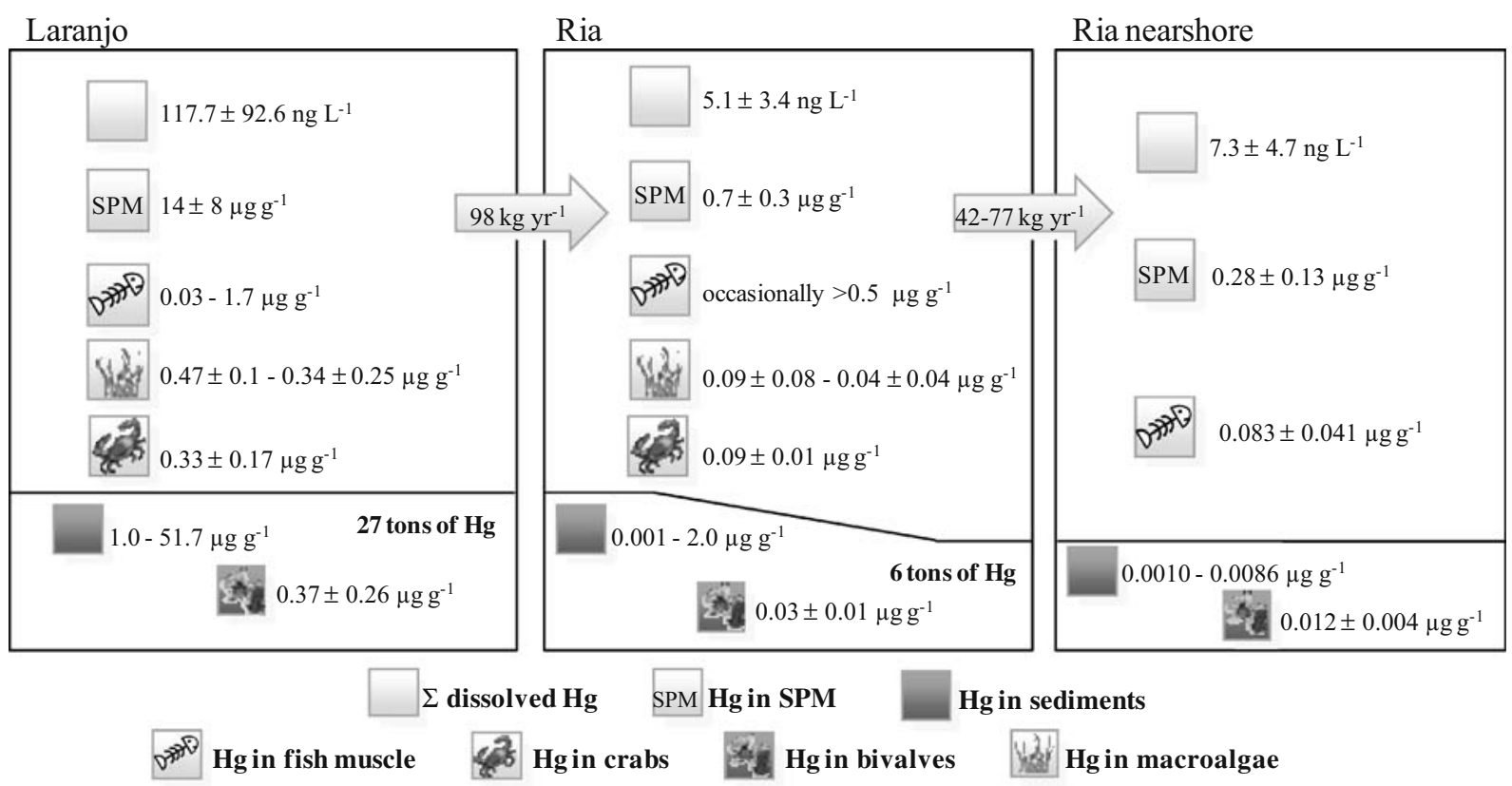

Fig. 2 Schematic representation of mercury contamination in abiotic and biotic environmental compartments of Ria de Aveiro (excluding the Laranjo bay), of Laranjo bay (Laranjo) and of Ria nearshore, and the fluxes of total mercury within the system and between the system and the nearshore Atlantic waters (mean values \pm std. dev; data references available in the text) 
(excluding the Laranjo bay), of Laranjo bay and of Ria nearshore, and the fluxes of total mercury within the system and between the system and the nearshore Atlantic waters is illustrated in Fig. 2. Within the system level (Fig. 2), the discharged mercury is known to be mostly sedimentassociated in the Laranjo bay (Pereira et al. 1998 b) being a minor fraction exported each tidal cycle by resuspended sediments (Pereira et al. 1998a). Fluxes between the most contaminated area and the main system were calculated in $98 \mathrm{~kg}$ $\mathrm{Hg}_{\text {year }}{ }^{-1}$ (Pereira et al. 1998a). During a tidal cycle, the levels of $\mathrm{Hg}$ showed an increase in suspended particulate matter (SPM) concentration during ebb tide (Monterroso et al. 2003; Ramalhosa et al. 2006) and calculations evidenced an additional hourly net export of $11 \mathrm{~g} \mathrm{Hg}$ by plankton in $63 \mu \mathrm{m}$ net, and of $6 \mathrm{~g} \mathrm{Hg}$ by plankton in $200 \mu \mathrm{m}$ net (Monterroso et al. 2003), meaning also that mercury is exported from the contaminated bay through the first levels of the estuarine chain (Abreu et al. 2000).

At the system/Atlantic ocean level (Fig. 2), an estimate range of values for the annual mass balance showed that the total mercury exported (dissolved and in SPM) to the nearshore ranged between 42 and $77 \mathrm{~kg}$, which can be considered comparatively low (Pato et al. 2008a). In addition dissolved and particulate mercury make little impact on the nearshore environment of the Atlantic Ocean (Pato et al. 2008b). Other systems, mostly contaminated by extinct chloralkali plants, namely Cartagena bay (Colombia), Ulhas estuary (India), Venice lagoon (Italy) and Bahía Blanca estuary (Argentina) showed lower mercury concentrations in sediments at the outer parts, away from the pollution source, than nearby the chlor-alkali plant (respectively, Alonso et al. 2000; Ram et al. 2003; Bloom et al. 2004; De Marco et al. 2006). However, in Pra river system (Ghana), although the highest concentrations corresponded to areas of active and past mining activities, mercury is most likely transported to depositional downstream terminal basins, like the river delta and the nearshore Gulf of Guinea (Donkor et al. 2006). Even so, it has been recognised that the wide variety of abiotic and biotic factors that influence mercury accumulation within a system conditioned the comparison and extrapolation of results to contaminated systems elsewhere (Abreu et al. 2000).

The recovery of the Aveiro's lagoon, namely the Laranjo bay, from mercury contamination is likely to remain a long-term issue. In fact, Pato et al. (2008a) calculated, based on the quantity of mercury exported per year to the Ocean, the recovery of the lagoon from contamination of deep sediments to last 300 years for $50 \%$ reduction. Bloom et al. (2004) also estimated that through the sediment transport to the Adriatic Sea it would take centuries before the Venice lagoon completely cleans itself from mercury contamination.

The differences between mercury exported from the most contaminated area to the main system and from the system to the Atlantic Ocean represents approximately $6 \mathrm{t}$ (Fig. 2), which may be mostly associated to sediment fine particles. A fraction of this amount may be incorporated into biota or transferred to the atmosphere. Nevertheless the concentrations so far determined in the different environmental compartments of Ria (excluding the Laranjo bay) do not seem to have long-term implications, particularly for "environmental health".

In Ria de Aveiro, in addition to the low transport of mercury to the coastal zone, the inefficiency of local marine sediments (low carbon levels and low fine fraction content) to trap mercury contributes to a dilution of mercury over a broader area, reducing the impact in the nearby marine coastal zone (Pato et al. 2008b).

In what concerns the terrestrial environment surrounding the lagoon and the impacts of mercury contamination on soil quality and on the terrestrial food chain, only a few studies have been developed so far (Inácio et al. 1998; Rodrigues et al. 2006a; Cachada et al. 2008). At an urban scale, the median concentration of total mercury in Aveiro town soils was $0.091 \mathrm{mg}$ $\mathrm{Hg} \mathrm{kg}{ }^{-1}$ (dry weight), and do not appear to constitute a risk for human health, since no direct effects of emissions of mercury from industrial activities nearby could be detected (Rodrigues et al. 2006b). Furthermore, comparatively to other European agglomerations, namely Glasgow, Ljubljana, Sevilla, Torino, and Uppsala, mercury levels in Aveiro urban soils are considered low 
(Rodrigues et al. 2006a). On the other hand, a study developed with the aim of assessing the extent of total mercury contamination in urban and agricultural soils from the town of Estarreja in the surroundings of the chlor-alkali plant (Cachada et al. 2008) reported that although mercury levels observed $\left(0.05-4.5 \mathrm{mg} \mathrm{Hg} \mathrm{kg}{ }^{-1}\right)$ were lower than those from previous studies (Inácio et al. 1998) in soils from the immediate vicinity of the chemical complex $(0.12-49 \mathrm{mg} \mathrm{Hg}$ $\mathrm{kg}^{-1}$ ) historical mercury contamination is still affecting the soil quality in the area.

\section{Conclusions}

Based on the results here presented it seems that mercury main contamination problems in Ria de Aveiro are confined to the small Laranjo bay, where mercury is strongly associated to sediments. Thus, as long as sediments of the most contaminated areas remain undisturbed by dredging activities, it does not resemble a risk to the nearshore environment. The biggest concern for mercury cycling in the Ria is the re-suspension of contaminated sediments by storm events and high-energy phenomena. Attending to mercury contamination levels within the Laranjo bay, macrophytes harvesting for direct or indirect Human uses and $\mathrm{Hu}-$ man consumption of Scrobicularia plana, Carcinus maenas and Dicentrarchus labrax captured within this inner area may constitute a risk for Human health. Regarding mercury levels in the terrestrial environment, no direct effects were detected in soils from the Aveiro area although enhanced levels of mercury where observed in agricultural soils from the vicinity of the chlor-alkali plant in Estarreja.

Presently, several research projects within the long-term variability of environmental quality of Ria de Aveiro regarding mercury are running in order to fulfil data gaps. Studies currently underway are focussed on mercury methylation in salt marshes, mercury biomagnification through the trophic chain, and on the effects of this historical contamination on the terrestrial food chain and potential impacts on local populations. Concerning the system "environmental health" the main goal consists in the development of skills for ecosystem restoration.

Acknowledgements This research was supported by FCT (Fundação para Ciência e a Tecnologia, Portugal) through CESAM and by the FCT Ph.D. grants: (SFRH/BD/11081/2002) (P. Pato); SFRH/BD/18682/2004 (M. Válega); (SFRH/BD/19509/2004) (J.P. Coelho). Soil analyses were conducted in the scope of the EU funded FP5 Project EVK4-CT-2001-00053: URBSOIL.

\section{References}

Abrantes, I., Dias, J. M., \& Rocha, F. (2006). Spatial and temporal variability of suspended sediments concentration in Ria de Aveiro and fluxes between the lagoon and the ocean. Journal of Coastal Research, 39, $718-723$.

Abreu, S. N., Pereira, E., Vale, C., \& Duarte, A. C. (2000). Accumulation of mercury in sea bass from a contaminated lagoon (Ria de Aveiro, Portugal). Marine Pollution Bulletin, 40(4), 293-297. doi:10.1016/ S0025-326X(99)00187-3.

Alonso, D., Pineda, P., Olivero, J., Gonzaález, H., \& Campos, N. (2000). Mercury levels in muscle of two fish species and sediments from the Cartagena Bay and the Ciê̂A naga Grande de Santa Marta, Colombia. Environmental Pollution, 109, 157-163. doi:10.1016/ S0269-7491(99)00225-0.

Baeyers, W., Leermakers, M., Papina, T., Saprykin, A., Brion, N., Noyen, J., et al. (2003). Bioconcentration and biomagnification of mercury and methylmercury in North Sea and Scheldt estuary fish. Archives of Environmental Contamination and Toxicology, 45, 498-508. doi:10.1007s00244-003-2136-4.

Bloom, N. S., Moretto, L. M., Scopece, P., \& Ugo, P. (2004). Seasonal cycling of mercury and monomethyl mercury in the Venice Lagoon (Italy). Marine Chemistry, 91, 85-99. doi:10.1016/j.marchem.2004.06.002.

Cachada, A., Rodrigues, S. M., Mieiro, C., Ferreira da Silva, E., Pereira, E., \& Duarte, A. C. (2008). Controlling factors and environmental implications of mercury contamination in urban and agricultural soils under a long term influence of a chlor-alkali plant in North-West Portugal. Environmental Geology, (in press). doi:10.1007/s00254-008-1284-2.

Cairrão, E., Pereira, M. J., Pastorinho, M. R., Morgado, F., Soares, A. M. V. M., \& Guilhermino, L. (2007). Fucus spp. as a mercury contamination bioindicator in costal areas (Northwestern Portugal). Bulletin of Environmental Contamination and Toxicology, 79, 388-395. Medline. doi:10.1007/s00128-007-9257-9.

Coelho, J. P., Pereira, M. E., Duarte, A., \& Pardal, M. A. (2005). Macroalgae response to a mercury contamina- 
tion gradient in a temperate coastal lagoon-Ria de Aveiro. Estuarine, Coastal and Shelf Science, 65, 492500. doi:10.1016/j.ecss.2005.06.020.

Coelho, J. P., Rosa, M., Pereira, M. E., Duarte, A., \& Pardal, M. A. (2006). Pattern and annual rates of Scrobicularia plana mercury bioacumulation in a human induced mercury gradient (Ria de Aveiro, Portugal). Estuarine, Coastal and Shelf Science, 69, 629-635. doi:10.1016/j.ecss.2006.05.027.

De Marco, S. G., Botté, S. E., \& Marcovecchio, J. E. (2006). Mercury distribution in abiotic and biological compartments within several estuarine systems from Argentina: 1980-2005 period. Chemosphere, 65, 213223. doi:10.1016/j.chemosphere.2006.02.059.

Dias, J. M., \& Fernandes, E. H. (2006). Tidal and subtidal propagation in two Atlantic Estuaries: Patos Lagoon (Brazil) and Ria de Aveiro Lagoon (Portugal). Journal of Coastal Research, 39, 1422-1426.

Dias, J. M., Lopes, J. F., \& Dekeyser, I. (2000). Tidal propagation in Ria de Aveiro Lagoon, Portugal. Physics and Chemistry of the Earth, 25, 369-374.

Directive 82/176/EEC (1982) Council Directive of 22 March 1982 on limit values and quality objectives for mercury discharges by the chlor-alkali electrolysis industry. Official Journal of the European Communities, L0176.

Donkor, A. K., Bonzongo, J. C., Nartey, V. K., \& Adotey, D. K. (2006). Mercury in different environmental compartments of the Pra River Bay, Ghana. Science of the Total Environment, 368, 164-176. doi:10.1016/j.scitotenv.2005.09.046.

EPA-United States Environmental Protection Agency (1997). Fate transport of mercury in environment. In: Mercury study report to congress (Vol. III). EPA452/R-97-005.

EPA-United States Environmental Protection Agency (2001). Water quality criterion for the protection of human health: Methylmercury, office of science and technology office of water. Washington: U.S. Environmental Protection Agency.

Inácio, M. M., Pereira, V., \& Pinto, M. S. (1998). Mercury contamination in sandy soils surrounding an industrial emission source Estarreja, Portugal. Geoderma, 85, 325-339. doi:10.1016/S0016-7061(98)00027-5.

Lawson, N. M., \& Mason, R. P. (1998). Accumulation of mercury in estuarine food chains. Biogeochemistry, 40, 235-247. doi:10.1023/A:1005959211768.

Lucas, M. F., Caldeira, M. T., Hall, A., Duarte, A. C., \& Lima, C. (1986). Distribution of mercury in the sediments and fishes of the lagoon of Aveiro, Portugal. Water Science and Technology, 18, 141-148.

Monterroso, P., Abreu, S. N., Pereira, E., Vale, C., \& Duarte, A. C. (2003). Estimation of $\mathrm{Cu}, \mathrm{Cd}$ and $\mathrm{Hg}$ transported by plankton from a contaminated area (Ria deAveiro). Acta Oecologica, 24, S351-S357. doi: 10.1016/S1146-609X(03)00033-X.

Pato, P., Lopes, C., Válega, M., Lillebø, A. I., Dias, J. M., Pereira, E., et al. (2008a). Mercury fluxes between a coastal lagoon (Ria de Aveiro, Portugal) and the Atlantic Ocean. Estuarine, Coastal and Shelf Science, 76, 787-796. doi:10.1016/j.ecss.2007.08.010.
Pato, P., Válega, M., Pereira, E., Vale, C., \& Duarte, A. (2008b). Inputs from a mercury-contaminated Lagoon: Impact on the nearshore waters of the Atlantic Ocean. Journal of Coastal Research, 24(2B), 28-38. doi:10.2112/05-0550.1.

Pereira, M. E., Abreu, S. N., Coelho, J. P., Lopes, C. B., Pardal, M. A., Vale, C., et al. (2006). Seasonal fluctuations of tissue mercury contents in the European shore crab Carcinus maenas from low and high contamination areas (Ria de Aveiro, Portugal). Marine Pollution Bulletin, 52, 1450-1457. doi:10.1016/ j.marpolbul.2006.05.006.

Pereira, M. E., Duarte, A. C., Millward, G. E., Abreu, S. N., \& Vale, C. (1998a). An estimation of industrial mercury stored in sediments of a confined area of the Lagoon of Aveiro (Portugal). Water Science and Technology, 37, 125-130. doi:10.1016/S0273-1223 (98)00191-7.

Pereira, M. E., Duarte, A. C., Millward, G. E., Abreu, S. N., \& Vale, C. (1998b). Tidal export of particulate mercury from the most contaminated area of Aveiro's Lagoon, Portugal. Science of the Total Environment, 213, 157-163. doi:10.1016/S0048-9697(98)00087-4.

Ram, A., Rokade, M. A., Borole, D. V., \& Zingde, M. D. (2003). Mercury in sediments of Ulhas estuary. Marine Pollution Bulletin, 46, 846-857. doi:10.1016/S0025326X(03)00065-1.

Ramalhosa, E., Segade, S. R., Pereira, E., Vale, C., \& Duarte, A. (2006). Mercury cycling between the water column and surface sediments in a contaminated area. Water Research, 40, 2893-2900. doi:10.1016/ j.watres.2006.05.023.

Rodrigues, S., Pereira, M. E., Duarte, A. C., AjmoneMarsan, F., Davidson, C. M., Grcman, H., et al. (2006a). Mercury in urban soils: A comparison of local spatial variability in six European cities. Science of the Total Environment, 368, 926-936. Medline. doi:10. 1016/j.scitotenv.2006.04.008.

Rodrigues, S., Pereira, M. E., Sarabando, L., Lopes, L., Cachada, A., \& Duarte, A. (2006b). Spatial distribution of total $\mathrm{Hg}$ in urban soils from an Atlantic coastal city (Aveiro, Portugal). Science of the Total Environment, 368, 40-46. doi:10.1016/j.scitotenv.2005. 09.088 .

Rothenberg, S. E., Ambrose, R. F., \& Jay, J. A. (2008). Mercury cycling in surface water, pore water and sediments of Mugu Lagoon, CA, USA. Environmental Pollution, (in press). doi:10.1016/j.envpol.2007. 12.013.

Válega, M., Lillebø, A. I., Pereira, M. E., Corns, W. T., Stockwell, P. B., Duarte, A. C., et al. (2008a). Assessment of methylmercury production in a temperate salt marsh (Ria de Aveiro Lagoon, Portugal). Baseline. Marine Pollution Bulletin, 56, 136-162. doi:10.1016/ j.marpolbul.2007.09.033.

Válega, M., Lillebø, A. I., Pereira, M. E., Duarte, A. C., \& Pardal, M. A. (2008b). Long-term effects of mercury in a salt marsh: Hysteresis in the distribution of vegetation following recovery from contamination. Chemosphere, 71, 765-772. doi:10.1016/ j.chemosphere.2007.10.013. 